\title{
Erratum to: Tricuspid Atresia With Progressive Ductal Restriction in a Fetus
}

\author{
Alexander Lowenthal - Ashwin Lal • \\ Elif Seda Selamet Tierney • Theresa A. Tacy
}

Published online: 13 September 2012

(C) Springer Science+Business Media, LLC 2012

\section{Erratum to: Pediatr Cardiol}

\section{DOI 10.1007/s00246-012-0391-8}

The original version of this article unfortunately contained a mistake. The name of a Co-Author [Elif Seda Selamet Tierney] was incorrect in the affiliation part of the published version. The correct name has been spelled-out below.

The online version of the original article can be found under doi:10.1007/s00246-012-0391-8.

A. Lowenthal · A. Lal · E. S. Selamet Tierney · T. A. Tacy ( $\square)$ Echocardiography Laboratory, Division of Pediatric Cardiology, Department of Pediatrics, Lucile Packard Children's Hospital, Stanford University, 750 Welch Road, Suite \# 325, Palo Alto, CA 94304, USA

e-mail: tatacy@stanford.edu 